\title{
The Dialectics of Competition Law: Sketching the Ordo-Austrian Approach to Antitrust
}

\author{
Oles ANDRIYCHUK ${ }^{\star}$
}

\begin{abstract}
This paper explores the qualitative (deontological) approaches to the phenomenon of economic competition, synthesizing the Ordoliberal and the Austrian perceptions of antitrust economics, policy and law. It critically addresses the main normative motto of the contemporary antitrust, embedded in the ethos of consumer/total welfare, as well as the methodological reduction of competition policy to the empirical analysis. Not contesting the paramount role of economics in the realm of antitrust, it demonstrates why the phenomenon of competition cannot be narrowed down to its welfare-generating function. By comparing the regulatory mechanisms of the competitive process in the real economy and sports it depicts some potential methodological analogies, between the two realms.
\end{abstract}

\section{INTRODUCTION}

This paper makes an attempt to recalibrate the main premises of the two deontological antitrust traditions - the Austrian and Ordoliberal Schools - in a symbiotic theory, which emphasizes the normative importance of competition, while recognizing the regulatory limits of its protection. The analysis of regulatory restraints of free competition reveals that, in addition to its internal dangers, the competitive process can often violate other significant societal interests and is therefore subject to limitations and restrictions. However, these regulatory limits do not influence the nature of competition, but only address the issues of its application. ${ }^{1}$ The internal significance of each value goes beyond the regulatory preferences and should be explored regardless of its actual status on the political agenda. This methodological premise opens a set of epistemological problems of

Oles Andriychuk (PhD) (EUI, Florence), Lecturer in Law at the University of Stirling. I am grateful to Profs Giuliano Amato, Heike Schweitzer and Hanns Ullrich for their inspiring seminars at the European University Institute, to my colleagues at the Centre for Competition Policy for providing a genuinely interdisciplinary environment as well as to an anonymous referee for her/his comments. The usual disclaimer applies.

Corwin D. Edwards, Big Business and the Policy of Competition 5 (University Cleveland 1956): '[F]or today the anti-trust laws [...] are often discussed as though the sole basis for evaluating them were their bearing upon the attainment of strictly economic goals. Undoubtedly the economic impact of the policy of competition must be fully considered. But our interest in abundance of goods and services, full employment of resources, stability, technological progress, and similar economic objectives cannot justify us in disregarding the political foundations of our free society.'

Andriychuk, Oles. 'The Dialectics of Competition Law: Sketching the Ordo-Austrian Approach to Antitrust'. World Competition 35, no. 2 (2012): 355-384.

(C) 2012 Kluwer Law International BV, The Netherlands 
balancing, revealing situations where different incompatible values are equally legitimate and should be protected by the decision-maker.

The analysis of the goals of competition law starts with an articulation of the methodological point that different approaches to competition should be conceptually separated into two doctrinal camps - utilitarian and deontological. The former includes those visions of antitrust that consider the competitive process as an instrumental value of market economy, ${ }^{2}$ implying that the efficiency (for economists), validity (for lawyers) and legitimacy (for political scientists and practitioners) benchmark of competition is based in its ability to deliver positive outcomes for the general welfare. ${ }^{3}$ As Kirchner submits, 'the efficiency goal as the ultimate social goal can only be defended in the context of a utilitarian philosophy'. In contrast, the deontological approach perceives the competitive process itself as a legitimate regulatory value. This approach may include both purely economic and broader, socio-economic goals. ${ }^{5}$ The latter cover those who claim that competition constitutes an important substantive democratic value that should not be measured only by its economic performance, since either the competitive process itself ${ }^{6}$ or other non-measurable objectives promoted by antitrust produce significant benefits for society. ${ }^{7}$ In other words, utilitarians measure competition externally, whereas deontologists address it from within.

My criticism of the utilitarian perceptions of antitrust is primarily of a methodological nature, though it contingently conforms to purely legal arguments. ${ }^{8}$ The societal importance of the economic interests which utilitarian views expect the competitive process to promote and enhance is not disputed. The

2 Rudolph J. Peritz, A Counter-History of Antitrust Law, 39 Duke L. J. 303(1990): 'This sort of justification for rules promoting competition, monopoly, or any other state of affairs might appear to be a modern form of utilitarianism: A rule is Good when its effect is a society that, overall, is better off (wealthier)'.

3 Robert H. Bork, The Antitrust Paradox - A Policy at War with Itself 51 (Basic Books 1978) :

"Competition", for purposes of antitrust analysis, must be understood as a term of art signifying any state of affairs in which consumer welfare cannot be increased by judicial decree.'

4 Christian Kirchner, Future Competition Law, in The Objectives of Competition Policy European Competition Law Annual 1997120 (Claus-Dieter Ehlermann \& Laraine L. Laudati eds., Hart Publishing Working Paper, 1998).

5 Franz Jürgen Säcker, Competition Law: European Community Practice and Procedure - Article-by-Article Commentary 5-6 (Günther Hirsch, Frank Montag \& Franz Jürgen Säcker eds., Sweet \& Maxwell 2008).

$6 \quad$ United States v. Aluminum Co. of America, 148 F.2d 416, 429 2d Cir. 1945: '[O]ne of [the] purposes of [the antitrust statutes] was to perpetuate and preserve, for its own sake and in spite of possible cost, an organization of industry in small units which can effectively compete with each other.'

7 Eleanor M. Fox \& Lawrence A. Sullivan, Antitrust - Retrospective and Prospective: Where Are We Coming From? Where Are We Going?, 62 N.Y.U. L. Rev. 944 (1987) : 'While a more efficient allocation of resources would probably result from competition as compared with more direct government intervention or blatant laissez-faire, $[. .$.$] improved resource allocation was never a norm for antitrust,$ nor a condition precedent to antitrust enforcement.'

8 Roger Zäch \& Adrian Künzler, The Development of Competition Law - Global Perspective 70 (Roger Zäch, Andreas Heinemann \& Andreas Kellerhals eds., Edward Elgar 2010) (emphasis in the original): 'In so far as the goal of competition law is at stake, the existing law and its constitutional base are clear. 
value claims of the utilitarian methodology do not pose problem, unlike the attribution of the task to achieve these economic goals to the competitive process. The utilitarian rationale implies that competition should only be protected to the extent of its ability to generate welfare effects; ${ }^{9}$ hence, rejecting deontological arguments as inessential, irrelevant or populist. ${ }^{10}$ The internalization of the welfare-centred values into the domain of competition has created a paradoxical situation where one economic phenomenon (i.e., competition) is semantically covered by the other (welfare). The consequences of this paralogism undermine the essence of competition. Defining the phenomenon of competition exclusively in terms of welfare-related effects is inconsistent, since it deprives the phenomenon of its intrinsic meaning - though competition itself cannot be operationalized without economic reasoning. ${ }^{11}$ If the influence of competition on welfare fully covered the scope of the concept, competition would merely constitute a taxonomic subsection of welfare and its separate normative articulation would become meaningless.

\section{GOALS OF COMPETITION LAW}

The principal normative question of antitrust - 'whether [... it] should seek to advance consumer welfare or total welfare, or ought to aim, instead, at protecting Wettbewerbsfreiheit or the "freedom to compete"12 - is impossible to address without answering a broader question - how and to what extent the specific public policies should correspond to and be conducted in accordance with the general public interests and goals. There are two conceptual approaches in this respect: hierarchical and pluralistic. The former subordinates all sectoral policies to a higher end and assumes that this meta-goal serves as a guiding principle for all particular policies. This approach is tied to a holistic vision of economic regulation. It centralizes (administratively, ideologically or both) the sectoral policies under the

Altering the goal from protecting freedom to compete and thus the competitive process to promoting consumer welfare would thus be an interpretation contra legem et contra constitutionem and would be illegal.'

9 Robert H. Bork, Resale Price Maintenance and Consumer Welfare, 77 Yale L. J. 951 (1968): '[A]ntitrust is concerned with competition because a competitive regime provides society with the maximum output that can be achieved at a given time with the resources available.'

10 Robert H. Lande, The Rise and (Coming) Fall of Efficiency as the Rules of Antitrust, 33 The Antitrust Bull. 430 (1988).

11 Jacob Viner, Schumpeter's History of Economic Analysis, 44 The Am. Econ. Rev. 897 (1954): 'There is no method of influencing ends which falls outside the legitimate scope of economic analysis except the employment of the hortatory method, the appeal to the emotions, and the appeal to authority. To deny any influence to economic analysis is to deny any role to reason in the formation by a sensible man of his system of ends.'

12 Viktor J.Vanberg, Consumer Welfare, Total Welfare and Economic Freedom - On the Normative Foundations of Competition Policy, Freiburg Discussion Papers on Constitutional Economics, 09/3, 2009, 1. 
common denominator of public economic interests, welfare and growth. ${ }^{13}$ These policies are being pursued solely for the benefits of the meta-goals. ${ }^{14}$ The autonomous nature of policies, which may diverge from the meta-narrative, is treated mainly from a consequentialist perspective, which seeks to explore how they can be instrumentalized for the common good.

Conversely, the alternative approach concentrates on the sectoral specificities of different policies. Anchored in the pluralist tradition, ${ }^{15}$ it does not seek to subordinate all sectoral particularities to a common goal but acknowledges instead that each policy develops its own, local goal, and is primarily oriented towards its achievement, which may not correspond to and might even conflict with other public (meta-) goals. This autonomy is tolerated both from the positive and normative perspective. The former refers to the lack of knowledge and regulatory resources to reduce all sectoral policies to the common goal, claiming that such option is hardly plausible outside of the authoritarian frame of planned economy. The latter suggests that the autonomy of public policies is beneficial for society as a whole, since it enables more articulated and independent development of those public and private sectors that are unlikely to be supported from the centralized, holistic perspective, since their total usefulness for society would be considered insignificant. The latter approach implies modesty in antitrust regulation. ${ }^{16}$

The process of subordination of lower values, interests and policies to the central meta-goal should not necessarily be performed through strong administrative intervention. Another means of subordination is based on the selection of a list of universally accepted, uncontroversial values, which play the role of a social yardstick for the appropriateness of each policy, either legitimizing or de-legitimizing given practices. In antitrust such a role is performed by the standard of consumer welfare. It is hard to find any reason not to support the interests of consumers, as reflected in their welfare. Yet, the subordination of every public policy to the achievement of this meta-goal is contentious, at best. The doctrinal expansion of meta-goals can be observed in many areas of economic

13 Robert H. Bork, The Goals of Antitrust Policy, 57 The Am. Econ. Rev. 242 (1967): 'My thesis is that existing statutes can be legitimately interpreted only according to the canons of consumer welfare, defined as minimizing restrictions of output and permitting, efficiency, however gained, to have its way.'

14 Joseph Farrell, Complexity, Diversity and Antitrust, 51 Antitrust Bull. 168 (2006): 'Is monoculture a risk in competition policy? I think so.'

15 Eleanor M. Fox, The Modernization of Antitrust: A New Equilibrium, 66 Cornell L. Rev. 1169 (1981).

16 Jonathan Faull, The Objectives of Competition Policy, European Competition Law Annual 1997,12 (Claus-Dieter Ehlermann, Laraine L. Laudati eds., Hart Publishing 1998): 'Competition law can't save the world. Other laws and policies address other aspects of the economic system. I believe we should remain modest in our goals. [...] In day to day work, most competition authorities. [...] believe that they are doing their best to ensure that the competitive process is functioning, to prevent at least the most egregious distortions of competition, and [only] thereby to assist consumer welfare.' 
policy. ${ }^{17}$ Its logical structure enables a universal reductionist application and administration. The consequentialist rationale can be observed, for instance, in such areas as intellectual property - as well as the protection of property in general - it becomes difficult simply to refer to property rights alone. ${ }^{18}$ Often it requires such external, welfare-related justification as the promotion of innovation, a better distribution of resources or incentives to invest. ${ }^{19}$

The pluralist vision opposes this approach: it puts forward that sectoral policies should be treated autonomously and that their particular goals should not be perceived exclusively as a means to reach the meta-goal. This approach would argue on a separate evaluation of different entitlements, including welfare effects as well as the right to compete and property rights - a concept too often underestimated in antitrust analysis. ${ }^{20}$

The holistic view is often developed within the utilitarian methodology, reducing all sectoral economic goals to the common denominator of welfare. The perception of competition in terms other than its positive impact on economic welfare is nonsensical from the methodological perspective of welfare economics. ${ }^{21}$ In contrast, pluralist views are usually deontological and defend the importance of each particular goal. Pluralists acknowledge that the conflicts between different goals are inevitable and that they should be addressed by the balancing test. However, balancing is understood as a complex dialectical process of interaction between the policies themselves and between the policies and the decision-maker, and not as a mechanical reduction of them to the utility, which every policy can eventually generate for the meta-goal.

This perception implies a two-step balancing analysis, where the first step should focus on the values, taken as ends-in-themselves; at the second stage, these

17 Wolfgang Kerber, Should Competition Law Promote Efficiency? Some Reflections of an Economist on the Normative Foundations of Competition Law, Marburg Papers on Economics, No. 09, 2007, 4: 'From [... the] theoretical perspective [of welfare economics] competitive market is only an instrument used to achieve efficient allocation'.

18 Maurits Dolmans, Robert O'Donoghue \& Paul-John Loewenthal, Are Article 82 EC and Intellectual Property Interoperable? The State of the Law Pending the Judgment in Microsoft v. Commission, 3 Competition Policy Intl. 107 (2007): 'The objectives of intellectual property rights [...] and competition law are essentially the same: both promote innovation to the benefit of consumers.'

19 Oles Andriychuk, Rediscovering the Spirit of Competition: On the Normative Value of the Competitive Process, 6 Eur. Competition J. 607 (2010), available at http://papers.ssrn.com/sol3/papers.cfm? abstract_id=1781512.

20 Rudolph J. Peritz, supra n. 2, at 266.

21 Wolfgang Kerber, supra n. 17, 4: 'From this welfare-theoretic perspective, it is plainly evident that efficiency is the ultimate goal, and if agreements between firms or mergers lead to a higher degree of efficiency, then they should be allowed. Balance between competition and efficiency effects, as it is assumed in Art. 81 (3) or (as an efficiency defence) in merger control, does not make much sense. It might be necessary to balance between positive effects on efficiency of a certain business behaviour ('pro-competitive effects') and negative effects on efficiency ('anticompetitive effects') but not between competition and efficiency'. 
values are then cross-checked and balanced. The first step is important to reveal and articulate the peculiarity of each value. It can be called inside-the-box-thinking. This is a methodological requirement of coherence. This stage is often missing in antitrust, since it is considered to be aimed at either the accumulation of welfare (total welfare standard) ${ }^{22}$ or its fair distribution (consumer welfare standard) ${ }^{23}$ Both still belong to the second step only, since neither represents the essence of the competitive process itself. To use Barnes's metaphor, ${ }^{24}$ the second-step analysis is concerned only with the increase of the size of the economic pie and/or the proper distribution of its slices, whereas the first step addresses the problem of its flavour, appearance and texture, referring to such non-verifiable empirically societal characteristics as culture and principles of freedom which the market process is based upon. Flavour-related questions mattered in the historical development of the goals of antitrust law, ${ }^{25}$ and they can be neither measured nor replaced by the efficiency yardstick. ${ }^{26}$

The main argument of the deontological perception of competition can be separated into a normative and a methodological part. Both are mutually dependent. The former suggests that competition constitutes an important societal value. The latter insists that the value of competition should be perceived separately from its beneficial and harmful consequences. This second aspect is the most controversial. It would be against the logic of commonsense to presume that an act, which significantly distorts some important societal value, can be considered pro-competitive. Yet, the central claim put forward does not relate to the authorization of these acts, but merely their perception through the lens of competition. The two-step test would first address the question whether the conduct is beneficial for competition or is an expression of competition; after the inside-the-box analysis is done, it would then question its legitimacy from a broader societal perspective.

Thus, in sports, virtually any significant distortion of the principle of fair play would be prohibited at the second level, but it should not prevent a purely

22 Robert H. Bork, supra n. 13, 251.

23 Eugène Buttigieg, Competition Law: Safeguarding the Consumer Interest. A Comparative Analysis of US Antitrust Law and EC Competition Law 3 (Kluwer 2009).

24 David W. Barnes, Antitrust Dialogue on Social Science, Cultural Values, and Merger Law, 33 Antitrust Bull. 624-625 (1988).

25 Eleanor M. Fox, supra n. 15, 1154, (emphasis in the original): '[T] he claim that efficiency has been the goal and the fulcrum of antitrust is weak at best. The values other than efficiency that underlie the commitment to power dispersion, economic opportunity, and competition as market governor demand equal attention.'

26 Eleanor M. Fox \& Lawrence A. Sullivan, supra n. 7, 956-959: '[T]he Chicago School defines competition in terms of efficiency; defines efficiency as the absence of inefficiency; defines inefficiency in terms of artificial output restraint; $[\ldots]$ and thus concludes that any activity that does not demonstrably limit output is efficient, and therefore pro-competitive. Thus, it "proves" that almost all business activity is efficient.' 
hypothetical (in terms of practical implications) but very important (in terms of methodological consistency) first-step analysis whether the prohibited rule enhances competition. Arguably, some actions that are against the principle of fair play do indeed enhance competition. They are seldom re-authorized, but such option is always available either directly - the authorized fights between the hockey players which render the game more attractive - or implicitly. The threshold of authorization depends on the context of the market and its proper definition goes beyond the scope of a theoretical analysis.

This methodological claim merely disentangles the instrumental aspects of values from their very essence. It does not argue in favour of any of them. It would be in accordance with this methodology for instance to recognize competition in all its forms as belonging to the phenomenon as such, and then prohibit some of its parts as unacceptable for public purposes, ${ }^{27}$ and it would be against this methodology to claim that some actions are pro-competitive to the extent that they (can) increase societal welfare ${ }^{28}$ or even that the lack of consumer harm immunizes anticompetitive conduct from antitrust sanctions ${ }^{29}$ - even if the real normative outcomes for the competitive process might be more beneficial in the second case. ${ }^{30}$ It is also in accordance with this methodology to deny outright that the protection of the individual freedom to compete lies beyond the boundaries of antitrust $^{31}$ (taken as an economic calculus exercise). But then the discussion would continue not in the realm of the methodology of balancing but in the realm of the normative definition of competition.

27 John Vickers, Concepts of Competition, 47 Oxford Economic Papers, New Series 4 (1995).

28 Leegin Creative Leather Products, Inc. v. PSKS, Inc., 551 U.S. 877 (2007): 'The rule [of reason] distinguishes between restraints with anticompetitive effect that are harmful to the consumer and those with pro-competitive effect that are in the consumer's best interest.'

29 John Temple Lang \& Robert O'Donoghue, The Concept of an Exclusionary Abuse under Article 82 EC, Global Competition Law Centre Research Papers on Art. 82 EC, 2005, 47: 'It could be argued, with some force, that $[. .$.$] there is no harm to the "structure of competition" that, ultimately, does not also$ lead to direct consumer harm. [...] Put differently, there can be no case for intervention under competition law where there is harm to the competitive process, but none to consumers.'

30 Peter J. Hammer, Antitrust beyond Competition: Market Failures, Total Welfare, and the Challenge of Intramarket Second-Best Tradeoffs, 98 Mich. L. Rev. 923 (2000) : 'Under contemporary doctrine, restraints of trade can be justified if the restraints are "pro-competitive", but what does it mean to be "pro-competitive"? [...] The answers that the Court often gives mark a departure from structural understandings of competition. Conduct is pro-competitive if it increases output, reduces price, or enables the parties to provide a product or service that would not otherwise be available.' See, e.g., NCAA v. Board of Regents, 468 U.S. 85, 102-104 (1984) '[...] It is easier to reconcile these criteria with a total welfare standard than with a competition-based standard.'

31 Robert H. Bork \& Ward S. Bowman, The Crisis in Antitrust, 65 Colum. L. Rev. 370 (1965) : 'If the social-policy argument makes sense, then we had better drop the per se rule in favour of one permitting the defence that cartels benefit small businessmen. Coexistence of the social-policy argument with the pro-competitive rules would introduce so vague a factor that prediction of the courts' behaviour would become little more than a guessing game.' 
The second major problem is disciplinary. It concerns the selection of an adequate apparatus to address antitrust issues. ${ }^{32}$ The value of the competitive process in antitrust is usually defined in non-efficiency, deontological terms. From the perspective of economics, non-efficiency goals are those, which are difficult or impossible to prove empirically, and/or could not be fitted into an equilibrium analysis. ${ }^{33}$ Deontological values are non-quantifiable and 'this [welfare-economics] approach cannot deal with constitutional issues. ${ }^{34}$ A possible solution is offered by constitutional economics, which perceives citizens' will as consumers' preference, internalizing thereby the broader notion of political rights into economic theoretical discourse, ${ }^{35}$ translating political values into the language of economics. Despite its significant impact on the positive analysis of liberty through the lens of economics, the normative implications of such a translation are rather limited, ${ }^{36}$ since positivist rationality fails to explain the irreducibly deontological origins of rights.

Leaving aside the difficulty of measuring quantitative values of efficiency, ${ }^{37}$ as well as the whole spectrum of terminological complications arising from the simplified perception of the goals of antitrust, ${ }^{38}$ the neoclassical methodology of equilibrium economics cannot deal with non-quantifiable values. ${ }^{39}$ It cannot address them in another way than by reducing them to some measurable characteristics. ${ }^{40}$ Kerber clarifies in this respect that "[f]or many economists it is hard to understand that there might be a real trade off between competition and efficiency'. ${ }^{41}$ From this perspective, antitrust policy faces a dilemma: it can either

32 Maher M. Dabbah, The Internationalisation of Antitrust Policy 57 (Cambridge University Press 2003): '[A]ntitrust law is interdisciplinary in nature. [... T] he involvement of various disciplines in antitrust law and policy and their development should be welcomed.'

33 Paul J. McNulty, Economic Theory and the Meaning of Competition, 82 Q. J. Econ. 639-640 (1968).

34 Christian Kirchner, supra n. 4, 119.

35 Wolfgang Kerber, supra n. 17, 16: 'As a consequence, it is possible to argue also from an economic perspective that competition law should not only take into account the effects of restrictive agreements, mergers, and business behaviour on consumer welfare but also on a set of protected rights of competitors and up- and downstream firms, which might suffer losses through the infringements of these rights'.

36 Norman P. Barry, Unanimity, Agreement, and Liberalism: A Critique of James Buchanan's Social Philosophy 12Pol.Theory 580 (1984).

37 Joseph F. Brodley, The Economic Goals of Antitrust: Efficiency, Consumer Welfare, and Technological Progress 62 N.Y.U. L. Rev. 1030 (1987): '[C]onsidered ex post, production efficiencies are the most measurable of the three types of efficiencies, while innovation and allocative efficiencies present severe measurement problems. Considered ex ante, none of the efficiencies appears measurable'.

38 Eleanor M. Fox \& Lawrence A. Sullivan, supra n. 7, 969-988.

39 Maher M. Dabbah, supra n. 32, at 18: 'Economists [...] equate competition with impersonal price-making, the most impersonal being the 'purest', whereas lawyers tend to view competition as rivalry among firms to sell goods or services'.

40 David W. Barnes, supra n. 24, 624: 'The nonefficiency goals are fairly characterized as lacking both serious theoretical foundation and substantial empirical support. How should we form policy in the absence of a rigorous analytical foundation when the nonefficiency have intuitive appeal'?

41 Wolfgang Kerber, supra n. 17, 4. 
consider competition as a purely deontological value, refusing thereby cost-benefit economic methods, or transform the competitive process into an economically definable value. The former approach is unrealistic because the dominant role of economics in antitrust is undisputable. The latter approach is false, as the reduction of the competitive process to its outcomes for consumers negates the very essence of competition.

The solution to this conundrum is twofold. Alongside the welfare-standard, economic analysis should apply other empirical techniques, which would help to articulate the competitive process independently from its effects on consumers and other derivative goals. A suggested yardstick could be the intensity of the competitive process, the level of engagement of rivals, as well as pre-Chicago structural analysis of the markets, though from the empirical economic perspective the assumption that 'the intensity of the competitive process is a function of the market form which [...] is defined [...] is nowadays considered obsolete', ${ }^{42}$ as 'general correlations between market structures and market performance are difficult to prove'. ${ }^{43}$ However, game theory, behavioural economics and IO can conduct various types of the experimental research without being predetermined by the yardstick of welfare/efficiency, which reveals the potential coupling points between the normative premises of the deontological antitrust schools and the methodology of the various Post-Chicago approaches.

The second alternative is the elimination of the monopoly of economics in antitrust analysis. Competition law should be open to the non-empirical deontological methods of other social sciences $;{ }^{44}$ all of them, including economics should 'capture [...] the pulse of the law', ${ }^{45}$ acknowledging its internal rationale, and not reducing the law to their own apparatus. ${ }^{46}$ Law, and antitrust law in particular, always deals with non-quantifiable values, and law can never be reduced

42 Franz Jürgen Säcker, above, 14.

43 Wolfgang Kerber \& Ulrich Schwalbe, in Competition Law: European Community Practice and Procedure Article-by-Article Commentary 221 (Günther Hirsch, Frank Montag, Franz Jürgen Säcker, Sweet \& Maxwell 2008).

44 Friedrich A. von Hayek, Competition as a Discovery Procedure, 5 Q. J. Austrian Econ. 13 (2002): 'The curious fact that the merits of competition cannot be empirically verified in precisely those cases in which it is of interest is also shared by the discovery procedures of science in general'.

45 Eleanor M. Fox, The Battle for the Sole of Antitrust, 75 Cal. L. Rev. 923 (1987).

46 Pierre Legrand, Econocentrism, 59 U. Toronto L. J. 216 (2009): 'Those who claim to have elicited a common denominator transcending laws and the places of laws, allowing for a mathematization of law, partaking in some sort of epistemological bilingualism, and permitting a rigorous Archimedean assessment (and ranking) of laws in terms of 'efficiency' are, in effect, positing a range of audacious postulates. [...] While law is indeed thoroughly cultural, as any serious archaeological research must reveal, economics is taken to operate on a more elevated plane, and on a more elevated ethical plane also, within a 'beyond' of culture, if you will, and specifically within a beyond of the law's naïveté or capriciousness as it manifests itself locally'. 
to a cost-benefit calculus. ${ }^{47}$ The relations between the solutions suggested by different disciplines should be taken under the balancing test. ${ }^{48}$ More convincing arguments would have priority, regardless of the methodology through which they are built. ${ }^{49}$ The difference between these approaches is not crucial, ${ }^{50}$ and the arguments are usually developed by mixing the methods of both.

In addition, non-efficiency-based methods cover a much broader spectrum of values than the right to compete, including market integration, environment, social cohesion and innovations as well as many others qualitative non-economic goals. ${ }^{51}$ All values can be measured empirically and addressed theoretically, yet not all values can be reduced to empirically testable data, and even the reduction of empirically testable values is a methodological premise, which includes elements of simplification or arbitrariness, ${ }^{52}$ since neither the welfare of consumers nor the wellbeing of society can be measured by economic methods exclusively. A purely economic analysis cannot provide an ultimate definition of consumer welfare, or protect it, ${ }^{53}$ and it does not eliminate the necessity of choices. ${ }^{54}$ The same holds true in respect to the benchmark of efficiency. ${ }^{55}$ It is a matter of definition either

47 Ernst-Joachim Mestmäcker, A Legal Theory Without Law: Posner v. Hayek on Economic Analysis of Law, Walter Eucken Institut, Beiträge zur Ordnungstheorie und Ordnungspolitik 174, Tübingen, Mohr Siebeck, 2007, http://papers.ssrn.com/sol3/papers.cfm?abstract_id=1168422, accessed on Dec. 23, 2009, 34-35: 'Legal rules in a free order are not end-related and must abstract from the multitude of individual plans they are to coordinate. In the economic analysis of law the key concepts - rational choice and efficiency - are end-related. The term efficiency is used to denote the allocation of resources in which value is maximized. [...] This implies that the end-relation of rules of individual conduct is taken for granted, the end being the maximisation of wealth'.

48 John J. Flynn, Legal Reasoning, Antitrust Policy and the Social 'Science' of Economics, 33 Antitrust Bull. 721 (1988): 'The legal process is constantly confronted with reconciling competing and conflicting moral values underlying its rules in light of the specific realities of individual disputes, role definitions, and the consequences of the decision. Indeed, this function is central to the legal process'.

49 John J. Flynn, Antitrust Policy and the Concept of A Competitive Process, 35 N.Y. L. Sch. L. Rev. 898 (1990): '[Different visions of competition] often involve balancing concerns for liberty and equality in the complex process of reconciling the need for protecting individualism and community'.

50 David W. Barnes, supra n. 24, 623.

51 John J. Flynn, 'Discussion' in David W. Barnes, supra n. 24, 638: 'I guess the best summary I have seen of those goals $[\ldots]$ is that which Professor Eleanor Fox derived from her study of the legislative history of the Sherman Act, namely: (1) dispersion of economic power for its own sake; (2) freedom and opportunity to compete on merits; (3) satisfaction of consumers (which would embrace some of the values put forth by economic analysis); and (4) protection of the competitive process as market governor'.

52 Richard S. Markovits, On the Inevitable Arbitrariness of Market Definitions, 47 Antitrust Bull. 573-577 (2002).

53 Thomas B. Leary, Freedom as the Core Value of Antitrust In the New Millennium, 68 Antitrust L. J. 556 (2001): 'There [...] is no such thing as an objectively determined consumer welfare'.

54 Herbert J. Hovenkamp, Distributive Justice and the Antitrust Laws, 51 George Washington L. Rev. 6 (1982): 'Most antitrust rules work to the benefit of some consumers but to the detriment of others'.

55 Eleanor M. Fox, The Efficiency Paradox, New York University Centre for Law, Economics and Organisation, Law \& Economics Research Paper Series, Working Paper No. 09-26, 2009, 6: 'There is no one thing called 'efficiency'. Conducts, transactions, and markets have efficiency and inefficiency properties at the same time, and the relative dimensions of each property are affected by assumptions regarding how well markets work'. 
to ascribe the balancing of multiple goals to antitrust itself, ${ }^{56}$ developing thereby 'the multiple objectives of antitrust', 57 including inter alia references to the purely deontological notions of justice ${ }^{58}$ and fairness, ${ }^{59}$ or (alternatively) to limit antitrust to the issues of the competitive process alone. This research proposes to adopt the latter path and to contextualize this narrowly defined competition policy into the broader regulatory framework, balancing the competitive process against other important societal values.

\section{PROBLEMATIC ASPECTS OF THE WELFARE-CENTRED GOALS}

As has been argued above, the reduction of the concept of the competitive process to its welfare-generating effects solves neither normative nor methodological difficulties in antitrust. The difference between consumer and total welfare may be defined in ideological rather than methodological terms: the former is directed to the interests of consumers sensu stricto, ${ }^{60}$ while the latter is more concerned with a total increase in welfare which would subsequently lead to an increase in efficiency and benefit consumers. This means that the latter often uses the benchmark of the former. The methodological question of the definition of welfare is unclear be it from the perspective of antitrust policy in general or antitrust economics in particular. While acknowledging the role of Bork in developing the theory of consumer welfare, Orbach, for instance, remarks that the use of the term 'welfare' is not correct from an economic perspective and that sound economic analysis should refer to consumer and total surplus respectively; ${ }^{61}$ the former referring to the interests of buyers and the latter to those of both buyers and sellers alike - thus, '[t]he yardstick for measuring the efficiency of the market outcome is simply the sum of consumer and producer surplus'. ${ }^{62}$ Peritz observes in this respect a misleading connotation of the term. ${ }^{63}$ Bork himself

56 Oliver Budzinski, Monoculture versus Diversity in Competition Economics, 32 Cambridge J. Econ. 317 (2008): '[S] ustainable pluralism of competition theories is an imperative for science and no temporary problem on the path to the ultimate solution'.

57 Harlan M. Blake \& William K. Jones, Toward a Three-Dimensional Antitrust Policy, 65 Colum. L. Rev. 422 (1965).

58 Louis B. Schwartz, 'Justice' and other Non-Economic Goals of Antitrust, 127 U. Pa. L. Rev. 1076 (1979).

59 Edwin J. Hughes, The Left Side of Antitrust: What Fairness Means and Why It Matters, 77 Marq. L. Rev. 266 (1993).

60 John B. Kirkwood \& Robert H. Lande, 'The Chicago School's Foundation is Flawed: Antitrust Protects Consumers, Not Efficiency', University of Baltimore Legal Studies Research Paper No. 2009-17, 2009, 3: 'The primary goal of antitrust actually is to prevent 'unfair' transfers of wealth from purchasers to firms with market power'.

61 Barak Y. Orbach, The Antitrust Consumer Welfare Paradox, 7 J. Competition L. \& Econ. 138 (2010).

62 Roger J.Van den Bergh \& Peter D. Camesasca, European Competition Law and Economics: A Comparative Perspective 23 (Sweet \& Maxwell 2006).

63 Rudolph J. Peritz, supra n. 2, 311: "Because the phrase "consumer welfare" shares semantic elements with the Ralph Nader consumerist movement, there has been a feeling that Robert Bork, Richard 
recognizes that his 'understanding of the benefits of competition for consumers is somewhat inaccurate, but that does not affect the fact that this is usually the primary value we have in mind'. ${ }^{64}$ His more severe critics argue that Bork's 'consumer welfare' has 'little or nothing to do with the welfare of true consumers'. ${ }^{65}$ The relation between the terms welfare and surplus is not synonymic. The former has a more articulated ethical meaning, while the latter remains within the realm of economic analysis. ${ }^{66}$ The same holds true for another yardstick, which is used in economics - the concept of efficiency. ${ }^{67}$

Accordingly, measuring welfare with the economic yardstick is more difficult than measuring surplus; the phenomenon of welfare, unlike that of surplus is not all about maximization. Arguably the former task goes beyond the scope of antitrust's economic apparatus. ${ }^{68}$ The importance of such limitation of neoclassical economics lies in its clarity. Antitrust should not primarily address welfare-related concerns and concentrate more on the measurable data of consumer and/or total surplus. Fox observes in this respect the selectivity of the Chicago School, which applies its welfare argumentation only if it prevents regulatory intervention and ignores it whenever the intervention can increase welfare. ${ }^{69}$ This epistemological characteristic of the Chicago School also shows that the notion of consumer welfare concerns broader issues of consumer wellbeing, which is impossible to perceive as a specific task of antitrust, inasmuch as it constitutes a meta-goal; namely, responsible economic governance in general. The limited attention paid to consumer surplus downgrades antitrust analysis to a form of economic pragmatism, revealing thereby more clearly the disciplinary boundaries of economics, and proving that competition should be addressed from different

Posner, and other price theorists share the Naderites' concerns for consumers. Nothing could be farther from the truth, we have learned. Where Naderites call for commercial firms to take social responsibility $[\ldots$,$] price theorists believe that firms only have a responsibility to their shareholders to$ maximize earnings'.

Robert H. Bork, supra n. 3, 61 .

Robert H. Lande, above, 434.

Anne Perrot, Appropriation of the Legal System by Economic Concepts: Should Conflicting Goals be Considered?, in Economic Theory and Competition Law 132 (Josef Drexl, Laurence Idot \& Joël Monéger eds., Edward Elgar 2009): '[I]t is difficult for competition authorities to take into account objectives that are not strictly in line with short-term consumer surplus'.

${ }^{67}$ Frank H. Knight, The Ethics of Competition, 37 Q. J. Econ. 581 (1923): 'Even in physics and engineering, 'efficiency' is strictly a value category; there is no such thing as mechanical efficiency'.

68 Barak Y. Orbach, above, 141: 'Antitrust law does not even pretend to address welfare optimization issues. Its methodology is all about surplus - perceived values in particular markets'.

69 Eleanor M. Fox, Consumer Beware Chicago, 84 Mich. L. Rev. 1717 (1986): 'It is true, as Judge Easterbrook points out, that Chicagoans invoke dynamic effects and possibilities. But they do so only when reliance on the dynamic effect will lead to nonintervention. Thus, Chicagoans will rely on a free-rider effect to argue that producers should be able to fix resale prices. [...] But Chicagoans do not invoke dynamic effects (e.g., preserving rivalrous interactions to enhance inventiveness) to support antitrust intervention'. 
methodological viewpoints - but not rejecting the leading role of economics in the process.

Another aspect of the same problem should be re-emphasized, namely the homonymy between the term competition as perceived in classical economic theory - and as it is taken in the political and cultural domains - and the term competition in its neoclassical sense. ${ }^{70}$ While the former encompasses the idea of a dynamic rivalry, the latter is a part of a purely methodological analysis. ${ }^{71}$ The state of perfect competition is an indispensable condition of equilibrium economics, ${ }^{72}$ which implies an 'imaginary construction" ${ }^{13}$ of a hypothetical situation when demand meets supply, the situation when the equality of marginal cost and price $^{, 74}$ is achieved. Every economic theory is either directly or implicitly influenced by this basic premise, ${ }^{75}$ which in turn downgrades the normative aim of rivalry dynamism of the competitive process. ${ }^{76}$ This might be partly due to the fact that from the neoclassical economic perspective the reference to the normative value of freedom is considered as a return to the theoretical past of economics, basing this perception essentially on the cumulative perception of knowledge, ${ }^{77}$ as opposed to its cyclical view, which is typical for other social science, and which is the approach par excellence in philosophy. Competition for equilibrium-based analysis is not a normative aim, but only an important methodological part of the economic reasoning. ${ }^{78}$

70 John R. Hicks, Wealth and Welfare 138 (Basil Blackwell 1981): 'The liberal, or non-interference, principles of the classical (Smithian or Ricardian) economists were not, in the first place, economic principles; they were an application to economics of principles that were thought to apply to a much wider field. The contention that economic freedom made for economic efficiency was no more than a secondary support'.

71 Mark Blaug, Is Competition Such a Good Thing? Static Efficiency versus Dynamic Efficiency, 19 Rev. Indus. Org. 37 (2001): ' $[\mathrm{I}] \mathrm{f}$ there is recognition of change at all, it is change in the sense of a new stationary equilibrium of endogenous variables in response to an altered set of exogenous variables; but comparative statics is still an end-state conception of economics'.

72 Paul J. McNulty, above, 642: 'Perfect competition, the only clearly and rigorously defined concept of competition to be found in the corpus of economic theory, which is free of all traces of business behaviour associated with 'monopolistic' elements, means simply the existence of an indefinitely large number of noncompeting firms'.

73 Ludwig von Mises, Human Action - A Treatise on Economics 237 (William Hodge and Co. 1949).

74 Thomas J. Di Lorenzo \& Jack C. High, Antitrust and Competition, Historically Considered 26 Econ. Inquiry 428 (1988).

75 John Vickers, above, 7: 'Perfect competition (including competitive equilibrium) models are extremely useful for analyzing all sorts of economic issues'.

76 Friedrich A. von Hayek, supra n. 42,10, (emphasis in the original): '[T] he absurdity of the conventional approach proceeding from a state in which all essential conditions are assumed to be known - a state that theory curiously designates as perfect competition, even though the opportunity for the activity we call competition no longer exists. Indeed, it is assumed that such activity has already performed its function'.

77 Friedrich A. von Hayek, Freedom, Reason, and Tradition 68 Ethics 231 (1958).

78 For a more detailed analysis of the difficulties, related to the homonymy problem, see Oles Andriychuk, The Concept of Perfect Competition as the Law of Economics: Addressing the Homonymy 
Economic approaches that emphasize the limited nature of equilibrium-based analysis $^{79}$ do not deny its methodological importance but they question its normative part. The notion of competitive process is not materially embedded, and most mainstream economic theories do not address it as a topic of research. The stylized or improved version of the concept of perfect competition refers to the notion of workable competition, which again perceives the competitive process as a means which is either tolerated (so far as it does not harm the normative premises and the framework of workability) or addressed only in its reduced, welfare-related form, referring to the formula 'what is good for welfare - is pro-competitive; what is not - is anticompetitive'. The economic definition of the competitive process may presume rivalry, ${ }^{80}$ but it always circumscribes the normative protection of competition to its positive consequences for measurable values, it does not consider any normative value in competition itself.

\subsection{The COMPetitive Balance}

As to the method which can be used to define competition separately from the beneficial incomes, which it generates, ${ }^{81}$ the role of the rivalry process, perceived as 'an effective competition structure' ${ }^{82}$ or as 'a medium of interrelation' 83 should be explored. The analogy between competition and sports - as well as games in general - could be of use. It is often used in economic, ${ }^{84}$ as well as in legal

Problem, 62 Northern Ireland Legal Quarterly, 523-538 (2011), available at http://ssrn.com/ so13/papers.cfm?abstract_id=2001319.

79 David B. Audretsch, William J. Baumol \& Andrew E. Burke, Competition Policy in Dynamic Markets, 19 Intl. J. Indus. Org. 614 (2001): 'In a dynamic economy competition in product and process innovations may have a more significant effect on welfare, at least in the long run, than does any likely variation in price'.

80 John M. Clark, What Is Competition?, 3 U. J. Bus. 220 (1925): '[C]ompetition extends to many forms of rivalry, most of which may be treated as subsidiary to the basic struggle of business enterprises making and selling goods, but which are nevertheless very different from each other. There is buyers' and sellers' competition, one-sided and two-sided competition, competition in price, in quality, in advertising and selling, and in securing access to the means of production. There is competition of consumers for goods, competition of different classes of workers to secure jobs, to hold the jobs they have secured, and to obtain advancement'.

81 Associated Gen. 459 U.S. 519, 528 (1983): 'Coercive activity that prevents its victims from making free choices between market alternatives is inherently destructive of competitive conditions and may be condemned even without proof of its actual market effect'.

82 Case 6/72 Europemballage Corp and Continental Can Co Inc v Commission [1973] ECR 215, para. 12 .

83 Oliver Budzinski, Cognitive Rules, Institutions, and Competition, 14 Const. Political Econ. 227 (2003).

84 Frank H. Knight, The Sickness of Liberal Society, 56 Ethics 91 (1946): "[F]or an understanding of the social ethic of liberalism, its general principles and their application to political and economic life, it is highly important to consider carefully the phenomena of play and the cultural pursuits'. 
analysis. ${ }^{85}$ It has been suggested that 'the final element in any contest $[\ldots$ is] the inherent unpredictability of [its] outcomes'. ${ }^{86}$

For many distinguished antitrust thinkers the protection of the competitive process as an end in and of itself is 'analytically disastrous' ${ }^{87}$ Yet, the same analytical approach shows that the multiplicity of societal goals directly related to antitrust cannot be reduced to a single denominator, and that the plurality of values requires a plurality of antitrust-related goals, ${ }^{88}$ treated analytically as separate. The competitive process in such synthetically separate analysis has an important, if not primordial, place. The importance of unpredictability (and therefore undefinability) of the competitive process is emphasized by the evolutionary economics. Farrell calls this feature the 'dark matter of competition'. ${ }^{99}$ Kerber explains the implications of this Hayekian approach, submitting that (i) competition can be perceived as a process 'in which previously unknown knowledge is generated, and (ii) the multiplicity and diversity $[\ldots]$ might be crucial for the effectiveness of competition as a discovery procedure'. ${ }^{90}$ Budzinski characterizes this approach as an open-ended continuum of experimentation, considering it as 'a research process in which the competitors try to improve their always limited, situative, and fallible knowledge on economic problem solutions'. ${ }^{91}$

Antitrust in this respect can also internalize the notion of competitive balance used, for instance, in sports economics. The competitive balance is a situation in team sports, where the governing body - sports league or federation intentionally maintains the correlative difference between the clubs, not allowing the discrepancy between them to exceed the established limit. A similar perception of the competitive process exists in economics, ${ }^{92}$ but it is mainly considered as

85 Giorgio Del Vecchio, Truth and Untruth in Morals and Law, in Interpretations of Modern Legal Philosophies: Essays in Honour of Roscoe Pound 150 (Paul Sayre ed., Oxford University Press 1981).

86 Stan Metcalfe, Ronald Ramlogan, Elvira Uyarra, 'Economic Development and the Competitive Process', Centre on Regulation and Competition Working Paper Series, No. 36, 2002, p. 12.

87 Robert H. Bork, supra n. 3, 59.

88 Rudolph J. Peritz, supra n. 2, 266: '[W]e can make antitrust law workable [...] by viewing it as the product of tensions between the rhetorics of competition policy and private property rights. [...]This structured analysis of antitrust discourse, which I call a 'genealogy' or a 'counter-history' [...] can revitalize an antitrust economy of pluralism'.

89 Joseph Farrell, above, pp. 168-169.

90 Wolfgang Kerber, Competition Policy and the Economic Approach: Foundations and Limitations 173 (Josef Drexl, Wolfgang Kerber \& Rupprecht Podszun eds., Edward Elgar 2011).

91 Oliver Budzinski, An Evolutionary Theory of Competition, University of Southern Denmark Department of Environmental and Business Economics Working Paper, 2004, http://papers. ssrn.com/sol3/papers.cfm?abstract_id=534862 accessed on Feb. 25, 2011, 4.

92 Robert Liefmann, Monopoly and Competition as the Basis of a Government Trust Policy, 29 Q. J. Econ. 318 (1915). 
outside the normative and methodological premises of welfare economics, either internalizing it to the concept of efficiency or ignoring the concept outright. ${ }^{93}$

Among the most common mechanisms for designing competitive balance are the following: draft system in North American professional leagues, which implies the worst team's priority in signing for new players at the end of the season; ${ }^{94}$ seeding in draws, which prevents the possibility for the strongest teams to participate in the early stages of knockout competition; ${ }^{95}$ revenue sharing, which binds the most commercially successful teams to redistribute part of their incomes with other participants of competition in order to maintain the integrity necessary for the league $;{ }^{96}$ salary cap, which prevents the richest clubs to sign the most skilful players; ${ }^{97}$ blackout rules, which prevent broadcasting of the most commercially attractive games of the tournament at the time when a local team plays its game in order to avoid the conflict of interests for potential viewers; ${ }^{98}$ financial contributions to the relegated teams, which enables the least successful teams to maintain their financial stability for the following years, affording them a second chance to get promoted to the higher league in the following seasons; ${ }^{99}$ collective selling of broadcasting rights, which helps to maintain coherency in distribution between the most and the less lucrative content of the tournament; ${ }^{100}$ compensation to the clubs which delegate their players to the national team, benefiting the clubs which were temporarily disadvantaged due to delegation of their best athletes to the national team; limitation of the mobility of the players by the reserve clauses, which does not allow the athlete to switch teams according to his will, preventing thereby the situational disproportions between the clubs; ${ }^{101}$ joint marketing which implies that the league promotes the tournament as a whole by single branding and by packaging media rights, enabling thereby a more proportional sharing of the audience between the different matches, and not

93 Wolfgang Kerber, supra n. 17, 10: 'Although most economists view economic freedom as very important, so far no convincing solutions have developed how to integrate an analysis of economic freedom with an industrial economics approach to competition'.

94 Mohamed El-Hodiri \& James Quirk, An Economic Model of a Professional Sports League, 79 J. Pol. Econ. 1304 (1971).

95 Allen J. Schwenk, What is the Correct Way to Seed a Knockout Tournament?, 107 Am. Mathematical Mthly. $140(2000)$.

96 Stefan Szymanski \& Stefan Késenne, Competitive Balance and Gate Revenue Sharing in Team Sports 52 J. Indus. Econ. 165 (2004).

97 Stefan Késenne, The Impact of Salary Caps in Professional Team Sports, 47 Scottish J Pol. Econ. 423 (2000)

98 Harry M. Shooshan, Confrontation with Congress: Professional Sports and the Television Antiblackout Law, 25 Syracuse L. Rev. 713 (1974).

99 Roger G. Noll, The Economics of Promotion and Relegation in Sports Leagues: The Case of English Football, 3 J. Sports Econ. 170 (2002).

100 Martin Cave \& Robert W. Crandall, Sports Rights and the Broadcast Industry, 111 Econ. J. 5 (2001).

101 Stephen Dobson \& John Goddard, Performance, Revenue, and Cross Subsidization in the Football League, 1927-1994, 51 Econ. Hist. Rev. New Series, 765 (1998). 
allowing the broadcasters and viewers to cherry-pick the games of the most attractive clubs only. ${ }^{102}$ In addition the rich literature in game theory ${ }^{103}$ and lottery analysis ${ }^{104}$ also provides purely economical standards for modelling contests.

Apart from the regulatory instruments, which are external to the contest as such, the internal rules of the game itself are designed in a manner to promote the elements of unpredictability, rivalry and performance of the teams. The task of this instrument is neither to create equality between the teams nor to increase their economic performance; it does not have one end-state. Both, equality and performance are important tasks in sports, but they are treated methodologically separately from the competitive balance, while remaining closely connected to it. The principle of the competitive balance is a dynamic, process-oriented goal; it does not pursue clear-cut objectives, though some of its methods are defined in this clear-cut manner. There is no best competitive balance: it encompasses both elements of unpredictability and competitive advantages, which the stronger teams have over their weaker opponents. Its task is not to eliminate the differences between the strength of the teams, but to create coherence between them, to make their involvement into sports more unpredictable and entertaining, which is the essence of sports contests, a notion very similar to economic competition in this respect. The purpose of it is the creation, protection and promotion of competition for its own sake. This method shows that irony towards the protection of freedom is not always correct on the substance, ${ }^{105}$ inasmuch as 'competition is valued for its own sake, as the economic equivalent of political democracy'. ${ }^{106}$

The competitive balance then obviously brings in monetised values, like revenues from attendance and selling media rights, sponsorship agreements and other marketing activities, but these consequences are indirect. The primary task of the competitive balance is competition. This analogy should not be taken literally. The difference between public economic policy and professional sports is important. The role of competition is not self-evident in economic life, while sports contest could not exist without competition, as it is embedded in rivalry by definition. However, the suggested analogy does not address normative issues and the substantive comparison therefore is irrelevant at this point. It is a proposal for

\footnotetext{
102 Daniel D. Manson, What Is the Sports Product and Who Buys It? The Marketing of Professional Sports Leagues, 33 Eur. J. Mktg. 403 (1999).

103 Ken Binmore, Modelling Rational Players: Part I, 3 Econ. \& Phil. 179 (1987).

104 John Morgan, Financing Public Goods by Means of Lotteries, 67 Rev. Econ. Stud. 761 (2000).

105 Robert H. Bork, Contrasts in Antitrust Theory: I, 65 Colum. L. Rev. 415 (1965): 'Suppose that, due to economies of scale, an industry of 500 firms becomes one of twenty. Is your liberty curtailed? [...] Is it the task of antitrust, in the service of the enlargement of individual liberty, to require the dissolution of the twenty firms into 500 , or perhaps 1000 ?'

106 Corwin D. Edwards, supra n. 1, 4.
} 
the economic methodology of measuring, defining, protecting and promoting the competitive process, as it is performed in sports economics. It does not compare the role of competition in sports and in economic life, but merely transposes an instrument available in economics of professional sports to the public economic activities.

The significance of the competitive process in the economic sphere is developed by a normative and not a methodological argument. It refers to the constitutional role that competition plays in liberal democracies and is not directly relevant to the suggested analogy, although the structural similarities between the two models are substantial. These similarities between sports competition and antitrust should not be underestimated. Budzinski argues that in sports unlike in economic relations competition exists for its own sake, suggesting that while 'in economic competition there is no definite goal, or, in other words, the race never ends. Instead of victory, the race itself represents the "goal". ${ }^{107}$ However, the interest of sports teams is not in winning trophies for their own sake, but in the continuous process of winning. In a temporal dimension the process can be extended to the contribution to the historical development of the club's traditions or conversely reduced to the winning in each episode of a game. The outcomes of the matches or results of the seasons are only the most obvious tasks of sports competition. Trophies and titles serve as benchmarks of success, but they cannot be reduced to the very essence of the competitive process. Thus competition in sports economics as well as other sectors of the economy is present in many dimensions and at many levels. ${ }^{108}$

The notion of competitive balance should not be confused with the balancing act either. The task of the former is to maintain the process while the latter aims at achieving a certain result via the balancing process. In the former the task is to maintain the balanced equilibrium between the teams, whereas the latter perceives balancing as a way to solve clashes between values. Both are equally important for the purposes of competition; the former refers to its essence, while the latter primarily addresses the necessity of proportional protection/restriction of competition in its correlation with other important public values. The latter, however, can be also perceived as a part of the competitive process itself, if taken as a competition between the different values for regulatory protection/restriction. Ultimately, the competitive balance in professional sports provides an illustration of economic analysis of the competitive process and serves as a counterargument to the claims that the impossibility to measure competition prevents its proper

\footnotetext{
107 Oliver Budzinski, supra n. 56, 297.

108 Phedon Nicolaides, An Essay on Economics and Competition Law of the European Community, 27 Leg. Issues Econ. Integration 14 (2000) : '[F]irms compete on many different dimensions. Constraining one or more dimension does not necessarily result in the weakening of overall competition.'
} 
economic analysis and that this justifies evaluating competition solely from the perspective of its impact on the surplus-based economic values. It does not address the issue of specificity of professional sports and its specific legal status in antitrust.

The notion that the competitive balance may serve as an objective of antitrust policy has been originally contested by Bork, who defined it in twofold terms: either (i) preserving rivalry for its own sake - rejecting this goal outright, arguing that '[o]ur society is founded upon the elimination of rivalry'; ${ }^{109}$ or (ii) maximizing competition - suggesting that this would 'require the dissolution of virtually all industrial and commercial organizations'. ${ }^{110}$ Bork's analysis is based on a purely holistic perception, which subordinates all economic policies, relevant to antitrust to the sole goal of consumer welfare. Some of his critics also use the holistic argument of the meta-goal of antitrust, suggesting that otherwise it will end up being a 'meaningless hodgepodge of conflicting, inconsistent, and politicised mini-policies'. ${ }^{111}$ Another version of this holistic approach combines the main goals of antitrust 'into a single working principle' of antitrust welfare. ${ }^{112}$ These approaches may indeed provide some clarity, but clarity is not the exclusive virtue of complex economic relationships. ${ }^{113}$ They inevitably contain the elements of multiple goals, variety of interests and diversity of approaches. ${ }^{114}$ This multiplicity of antitrust-related objectives is embraced in the pluralistic methodology, which enables to address them under the balancing test, without making ex ante judgements on the normative significance of each value, internalizing indeterminacy into antitrust analysis, rather than considering it to be an obstacle for decision-making process.

\section{TOWARDS ORDO-AUSTRIANISM}

The role of competition in the market process has been mostly emphasized by the representatives of the two deontological antitrust schools: Ordoliberalism and Austrianism. Despite significant ideological differences between them, their development was to a large extent cross-fertilizing, creating a ground for debates

Robert H. Bork, supra n. 3, 58.

Robert H. Bork, supra n. 13, 252.

Herbert J. Hovenkamp, Antitrust Policy after Chicago, 84 Mich. L. Rev. 234 (1985).

Joseph F. Brodley, supra n. 37, 1023-1024 (emphasis in the original).

113 Lawrence A. Sullivan, The Viability of the Current Law on Horizontal Restraints, 75 Cal. L. Rev. 890 (1987): 'There are varieties of modern thought-political, sociological, economic, humanistic. To be worth reading, an antitrust opinion, like any thoughtful essay, must take shape and colour from one or more of these sources'.

114 Oliver Budzinski, supra n. 56, 295: 'Diversity in competition economics is advocated in two ways. First, competition economics is empirically characterized by a considerable pluralism of theories and policy paradigms. Second, it is demonstrated that this diversity of theories is theoretically beneficial for future scientific progress.' 
about the methods of protecting competition. ${ }^{115}$ Both contributed to the analytical disentanglement of competition from welfare. These two schools can hardly be jointed into a coherent theoretical vision of antitrust, but the arguments of both may be perceived as mutually-invigorating, if taken from a dynamic dialectical perspective. The dialectics of Ordo-Austrianism is based upon three main polarities: (i) competition as an individual right; (ii) competition as a collective right; (iii) the role of government in the regulation of the competitive process. ${ }^{116}$

Competition as an individual right is perceived by Ordoliberalism separately from economic efficiency, which it generates, ${ }^{117}$ primarily from the perspective of the underprivileged market-players. The individual right to compete should be broader than the possibility for successful companies to profit from their entrepreneurial discovery or natural monopolistic status. The right to compete should be also provided for other, less successful companies. ${ }^{118}$ This approach is similar to the intentionalist perception of antitrust, which claims that intervention to remedy imbalances of wealth and power is necessary to insure true individual freedom'. ${ }^{119}$ Individuals are perceived 'as ends in themselves and not as the means of another's welfare'. ${ }^{12}$ This entails the necessity of designing the rules, which both actively protect competition and enhance it. The regulatory intervention in this respect is not necessarily concerned with the limitation of market freedom, ${ }^{121}$ but should be rather seen as 'regulation as framing of market processes'. ${ }^{122}$ The

115 Viktor J.Vanberg, The Freiburg School: Walter Eucken and Ordoliberalism, Freiburg Discussion Papers on Constitutional Economics, 04/11, 2004, 3: 'It is apparent [...] from Röpke's report that he considered the exchange between Eucken and von Mises to be symbolic of a conflict of opinion that, as he notes, repeatedly resurfaced within the Mont Pelerin Society. And, indeed, Eucken and von Mises represent, with their respective works, two distinctively different perspectives on the nature of the liberal market order and the role of economic policy.'

116 Oles Andriychuk, supra n. 19, 581-583.

117 Stephen Martin, Issues in Competition Law and Policy 60 (Wayne D. Collins ed., American Bar Association Publishing 2008): 'In the Ordoliberal view, the overriding goal of competition policy was to maintain individual freedom; efficiency in an economic sense was an implied, but subsidiary, purpose.'

118 Edward N. Megay, Anti-Pluralist Liberalism: The German Neoliberals, 85 Pol. Sci. Q. 429-430 (1970): ‘The neoliberals are concerned over the availability of meaningful choices of action, not for the powerful but for the powerless or weak members of society. Hence they reject not only all autocratic and totalitarian regimes but also [...] the social effects of capitalism both of the Manchester and the social Darwinist variety.'

119 William H. Page, Legal Realism and the Shaping of Modern Antitrust, 44 Emory L. J. 14 (1995).

120 Wernhard Möschel, German Neo-Liberals, and the Social Market Economy 148 (Alan Peacock \& Hans Willgerodt eds., The Macmillan Press 1989).

121 Maurizio Lazzarato, Neoliberalism in Action: Inequality, Insecurity and the Reconstruction of the Social, 26 Theory Culture Socy. 117 (2009) : 'The market and competition are the result of a construction that requires a multiplicity of interventions, particularly from the state, having constitutive effects on both economic and non-economic conditions necessary for "laissez-faire" to exist and function.'

122 Viktor V. Vanberg, Markets and Regulation: On the Contrast between Free-Market Liberalism and Constitutional Liberalism, 10 Const. Pol. Econ. 220 (1999) (emphasis in the original). 
concerns of the market structure are not peculiar to Ordoliberalism only. Similar issues helped in designing the US antitrust rules, where the protection of the entrepreneurial freedom of small and medium undertakings played a significant role, ${ }^{123}$ which was particularly visible during Wilson's presidency. ${ }^{124}$ These views were dominating in the development of antitrust rules. According to the US Congress, "[competition is an interaction between two great forces, which are] corrective of each other, and both ought to exist. Both ought to be under restraint'. ${ }^{125}$ Though this approach has been severely criticized for being formalistic if not misleading, ${ }^{126}$ the criticism cannot remove the individual freedom to compete from the list of constitutional values in liberal democracies. ${ }^{127}$

Ordoliberalism protects the individual right of weaker companies, while the Austrian School addresses the demands of stronger companies to run their activities without significant regulatory corrections of the market process. ${ }^{128}$ Competition taken from this perspective is seen as the voluntary pursuit of gain'. ${ }^{129}$ The former therefore emphasizes the egalitarian vision of the individual right to compete, while the latter bases its arguments on the meritocratic perception of this right. Austrians reject the institutional framework, which guarantees to the competitors the ability to participate in the market process. Instead, they emphasize the consumer's possibility to decide upon the role of each competitor in the laissez-faire exchange system. ${ }^{130}$ Perceiving competition as a 'dynamic rivalry', ${ }^{131}$ Austrians support the right of the market participants to benefit from their successful performances, and not to share their gains with less successful opponents. This entails the protection of the right to gain by competing, and not

David W. Barnes, supra n. 24, 625.

Eleanor M. Fox, supra n. 15, 1148.

21 CONG. REC. 5956 (1890) (First Conference Report).

126 Heike Schweitzer, Technology and Competition: Contributions in Honour of Hanns Ullrich 514 (Josef Drexl, Reto M. Hilty, Laurence Boy, Christine Godt \& Bernard Remiche eds., Larcier 2009): '[T]he established focus on the competitive process, resulting from the exercise of individual rights to compete, is now being blamed for having (mis)led competition law to protect inefficient competitors.'

127 Paul H. Brietzke, The Constitutionalisation of Antitrust: Jefferson, Madison, Hamilton and Thomas C. Arthur, 22 Val. U. L. Rev. 297 (1988) (emphasis in the original): 'Topco goes on to echo the Equal Protection Clause of the fourteenth amendment: "every business, no matter how small", "has the freedom to compete - to assert with vigour, imagination, devotion, and ingenuity whatever economic muscle it can master" (United States v. Topco Assocs., Inc., 405 U.S. 596, 611 (1972)).

128 Murray N. Rothbard, Man Economy and State - A Treatise on Economic Principles, 641 (Ludwig von Mises Institute 2009).

129 Robert Liefmann, supra n. 91, 317.

130 Ludwig von Mises, supra n. 73, 275: '[Catallactic competition] is not a right, guaranteed by the state and the laws, that would make it possible for every individual to choose ad libitum the place in the structure of the division of labour he likes best. To assign to everybody his proper place in society is the task of the consumers. Their buying and abstention from buying is instrumental in determining each individual's social position. Their supremacy is not impaired by any privileges granted to the individual qua producers.'

131 Israel M. Kirzner, Entrepreneurial Discovery and the Competitive Market Process: An Austrian Approach, 35 J. Econ. Lit. 68 (1997). 
the right to compete regardless of performance. Such a view is based on normative individualism, a theory also developed in constitutional economics. ${ }^{132}$ According to this principle, 'no 'social' values exist apart from individual values'. ${ }^{133}$ Normative individualism does not reject the necessity of broader societal interests but it judges that the pursuit of individual interests would eventually have positive effects for society as a whole. Austrians are also methodological individualists; which, according to Nozick, implies 'that all true theories of social science are reducible to theories of individual human action, plus boundary conditions specifying the conditions under which persons act'. ${ }^{134}$

The second distinction is in the perception of competition as a collective right. According to the Ordoliberal principles, which have their intellectual roots in the US institutional theory, ${ }^{135}$ society should be based upon the principles of free competition. This rationale is not limited to enabling the individuals to compete, but also relies upon broader societal premises, that neither actual nor passive individual right to participate in competition fully covers its economic, political and cultural significance. Society as a whole benefits from competition, including those members and institutions, which do not participate in it directly. ${ }^{136}$ This approach is similar to the reason for protecting free speech. As Grimm points out, ${ }^{137}$ this freedom is provided not only for those who express their views, but also (primarily - for some) for those who consume the information, delivered by the media, 'producing an informed public capable of conducting its own affairs'. ${ }^{138}$ Freedom does not necessarily have to be realized or actualized by every member of society. Freedom's very availability is often as important as its direct benefits. Competition is not considered as an exclusive value, but its importance is not defined by other values. Müller-Armack in his concept of social market

132 Christian Kirchner, supra n. 4, 521: 'If economics shall be used as guidance for solving the [antitrust] problems $[\ldots t$ the utilitarian efficiency concept has to be given up and substituted by a concept of normative individualism (developed by constitutional economics and normative new institutional economics).'

133 James M. Buchanan, Fiscal Theory and Political Economy 118 (James Buchanan ed., University of North Carolina Press 1960).

134 Robert Nozick, On Austrian Methodology, 36 Synthese 353-354 (1977) , (emphasis in the original).

135 John B. Clark \& John M. Clark, The Control of Trusts 62 (Macmillan 1911): 'Competition and its purpose are not individual but social. [...] It is not a natural state, but like any other form of liberty, it is a social achievement.'

136 Michel Foucault, Geschichte der Gouvernementalität II: Die Geburt der Biopolitik, 173 (Suhrkamp, 2004), quoted and translated in Nils Goldschmidt, Hermann Rauchenschwandtner, 'The Philosophy of Social Market Economy: Michel Foucault's Analysis of Ordoliberalism', Freiburg Discussion Papers on Constitutional Economics, 07/04, 2007, 22: 'Pure competition should and can only be an objective, an objective that accordingly requires very active policies. Competition is thus a historical objective of governance, it is not a natural given that should be respected.'

137 Dieter Grimm, Extreme Speech and Democracy 16 (Ivan Hare \& James Weinstein eds., Oxford University Press 2009) .

138 Red Lion Broadcasting Co. v. FCC 395 US 367 (1969). 
economy proposes the irenic, peaceful coexistence of different views and values, claiming that difference in goals and views should be 'accepted as a given, which however does not terminate the effort to achieve unity'. ${ }^{139}$ The presumption that unregulated competition would lead to a better, more intensive competition is contested by reference to the natural instinct of 'the established firms [...] to garner the power to place roadblocks before their competitors'. ${ }^{140}$

The social function of economic competition has not been denied by the Austrians, but their libertarian methodology suggests that such a goal could be best achieved if economic actors were allowed to pursue their activities without significant regulatory encroachments, perceiving antitrust regulation as one of the most invasive. ${ }^{141}$ No successful individual is interested in living in a poor environment, and he or she cannot erect a wall between his or her wealth and others' poverty; in addition his or her self-interested behaviour directly and indirectly benefit the society as a whole, inasmuch as he or she is constantly sharing his or her profits by further investment in long-term projects, paying taxes or simply by spending his or her wealth and creating economic opportunities for his or her neighbours. In addition, Austrians argue that the more lucrative the gain is the more potential competition it generates, ${ }^{142}$ since rivals are impelled to explore innovative techniques in order to compete successfully. ${ }^{143}$ This creates a competitive environment, which fully covers societal interests in competition as a collective right.

Both schools also emphasize in this respect the paramount role of the spontaneity in market interactions, considering it as the main integrative force of societal life in general and in economic relations in particular. ${ }^{144}$ Although the

139 Alfred Müller-Armack, Religion und Wissenschaft: Geistesgeschichtliche Hintergründe unserer Europäischen Lebensform, 563 (Stuttgart 1981), , translated and quoted in Friedrun Quaas, Social Market Economy History, Principles and Implementation - From A to Z, 417 (Rolf H. Hasse, Hermann Schneider \& Klaus Weigelt eds., Ferdinand Schöningh 2008).

140 Eleanor M. Fox, supra n. 15, 1180.

141 Thomas J. Di Lorenzo \& Jack C. High, supra n. 74, 424.

142 Robert Liefmann, supra n. 91, 316-317: '[N] early all monopolies are relative monopolies, and are the more destructive to themselves, the more they lead to actual monopoly effects, as expressed in prices. [...] The survival of the economically strongest in the competitive struggle [...] leads to monopoly, but at the same time gives a new impetus to free competition, so that the more an acquired monopoly position is exploited, the sooner the competitive struggle is renewed.'

143 Jonathan B. Baker, Beyond Schumpeter vs. Arrow: How Antitrust Fosters Innovation, 74 Antitrust L. J. 579-581 : '[There are four main principles relating competition and innovation]: [(i)] competition in innovation itself [...]; [(ii)] competition among rivals producing an existing product encourages those firms to [develop new strategies [...]; [(iii)] firms that expect to face more product market competition after innovating have less incentive to invest in R\&D [...]; [(iv)] a firm will have an extra incentive to innovate if in doing so it can discourage potential rivals from investing in R\&D'.

144 Alan Peacock \& Hans Willgerodt, Overall View of the German Liberal Movement, in German Neo-Liberals, and the Social Market Economy 7 (Alan Peacock \& Hans Willgerodt eds., The Macmillan Press 1989): 'The disagreement between the two groups [Ordoliberals and Austrians] lay in an empirical matter. Would monopolies simply disappear in a 'gale of creative destruction' [...] or, as Lutz thought, be like 
notion of 'spontaneous order' is associated with Hayek, it was Röpke, an Ordoliberal thinker, who coined the term, or rather borrowed it from the philosophy of Mill and applied it to the twentieth century's economic context. ${ }^{145}$ The visions of spontaneous order significantly differ between the two schools. In some sense the ecology-anatomy analogy ${ }^{146}$ of the nature of society can be relevant to understanding this difference. The ecological vision of the spontaneous order perceives individuals as autonomous entities, mostly interested in perusing their own interests. Their behaviour should not be necessarily dictated by other participants, but it is in their interests to take the preferences and habits of these participants into account, and to model their market strategies accordingly. The anatomical view recognizes the autonomy of individual actors, but acknowledges the absolute necessity of coordination and subordination. The participants in the competitive process cannot always design appropriate rules for their behaviour without elements of coordination. While the ecological vision emphasizes the coexistence of market-players, the anatomical approach stresses the necessity of harmonious non-intrusive subjection to common rules, which regulate the emanations of such spontaneity in the market process. Both recognize the significance of spontaneity and some elements of coordination. This prevents the former from sliding down into radical anarchism and the latter from transforming into interventionism and collectivisim. While both systems are rather theoretical constructs and can hardly exist in practice, the Austrian vision would potentially correspond to the ecological perception of the spontaneous order, whereas the Ordoliberal approach is closer to the anatomical one.

Hayek perceives the origins of such regulatory approach of economic freedom in 'two different traditions in the theory of liberty'. ${ }^{147}$ The first is based on the principles of spontaneity, the second originates from design; tracing them back to Hume's empiricism and Descartes' rationality - and to ancient Rome and Greece on one hand and Sparta on the other. Popper suggests in this respect that the struggle between empiricism and rationalism is among the most important issues in the history of modern philosophy, explaining that it was Kant 'who tried to offer some synthesis - a compromise, or rather, a modified form of empiricism, ${ }^{148}$ or rather to reject pure rationalism. Leaving Hayek's normative criticism of the latter aside, his observation is important to show the discursive

'soap bubbles' which burst under competitive pressure; or would it not be possible for entrenched monopolies to develop in defiance, rather than as a consequence, of state action'?

145 John P. Bladel, Against Polanyi-Centrism: Hayek and the Re-Emergence of 'Spontaneous Order', 8 Q. J. Austrian Econ. 23 (2005).

146 Evelyn L. Forget, Jean-Baptiste Say and Spontaneous Order, 33 Hist. Pol. Econ. 198 (2001).

147 Friedrich A. von Hayek, supra n. 77, 229

148 Karl R. Popper, What is Dialectic?, 49 Mind 414 (1940). 
nature of the two approaches, ${ }^{149}$ and their dialectical interdependence. This is a Hegelian perception of the contradictions between the two wings of liberalism, ${ }^{150}$ which emphasizes the tensions between the schools, their joint support of the competitive process and common opposition towards welfare-exclusivity in antitrust analysis. Although usually the protection of competition as an individual right and as a collective right is perceived jointly, some authors contrast them. ${ }^{151}$

The third difference is closely related to the former two and concerns the polar perception of the role of the State in protecting and enhancing the competitive process. The Austrian School relies upon laissez-faire values, promoting the self-correcting force of the market, which 'can surely not be meant to imply the notion of a market without any rules', ${ }^{152}$ requiring governmental protection of fundamental economic rights, while this protection is perceived with a particular suspicion, as ' $[t]$ here is no other planning for freedom and general welfare than to let the market system work'. ${ }^{153}$ The Ordoliberal approach in this respect is closer to the paternalistic methods. The latter view is based on the tragic experience of Germany's past, when political, cultural and economic competition have been severely oppressed by participants in the process. ${ }^{154}$ This implies that the enhancement of the competitive process should not be perceived as a natural evolutionary process, but should be conducted by a responsible regulator, the primary task of which is to design within the framework of Ordnungspolitik (which is 'the principal method by which the general working properties of the market process can be deliberately shaped') ${ }^{155}$ the universal rules of the competitive games and to correct the game when it is not going on properly. The rules are designed and governed by institutions, and competition is a synthetic,

149 Friedrich A. von Hayek, supra n. 77, 230: 'Though these two groups are now commonly lumped together as the ancestors of modern liberalism, there is hardly a greater contrast imaginable than that between their respective conceptions of the evolution and functioning of a social order and the role played in it by liberty'.

150 Karl R. Popper, supra n. 147, 416: '[Hegel] simply said that contradictions do not matter. They just have to occur in the development of thought and reason. [...; reality, is not something fixed once and for ever, but that it is developing - that we live in a world of evolution'.

151 Jonathan Faull, supra n. 16, 12: '[T] he notion that we are protecting economic freedom [...] has impaired the interpretation of Art. [101...]. Two groups have emerged: those who believe that the objective of Art. [101] is to protect people's freedom to act, and those (amongst whom I count myself) who believe that the objective of Art. [101] is to protect the process of competition'.

152 Viktor J.Vanberg, supra n. 114, 5 (emphasis in the original).

153 Ludwig von Mises, Planning for Freedom and Twelve Other Essays and Addresses, 17 (Ludwig von Mises ed., Libertarian Press, 1974).

154 Lawrence A. Sullivan \& Wolfgang Fikentscher, On the Growth of the Antitrust Idea, 16 Berkeley J. Intl. L. 215 (1998): 'One of the [...] teachings of the Freiburg School is that liberty, if not protected by law, may abolish itself. [...] Hitler's election as a dictator, achieved under the liberal and democratic Weimar constitution (1919), was a political illustration of the same phenomenon.'

155 Viktor J.Vanberg, supra n. 12, 13. 
created rather than organic and natural process. ${ }^{156}$ The competitive markets constitute a very delicate model, and their development should be performed not only for their own sake, but also in a harmonious balancing with other important societal interests. The difference between the two deontological antitrust visions dialectically internalizes Peritz's dilemma of free competition. ${ }^{157}$

The combined Ordo-Austrian perception of competition can be based upon two programmatic statements: (i) the competitive process constitutes an important economic right - which, without denying the significance of economic outcomes, ${ }^{158}$ should not be subordinated to and measured by the standards of welfare/efficiency; (ii) competition is an important tool for evolution, innovation and economic progress. ${ }^{159}$ The former thesis is of a legal nature; the second is economic.

Both schools agree that competition brings prosperity and growth, and methodologically disentangle the outcomes of competition from its ethical constitutional significance. Although none of them is a purely ethical theory, as most of their representatives were economists, who are usually deemed to take into account the outcomes of the competitive process. This is particularly the case for the social market economy wing of Ordoliberalism ${ }^{160}$ as well as for the Austrians' consequentialist justification of the free market. ${ }^{161}$ However, alongside this economic consequentialism, both theories are supported by strong normative claims related to the theory of rights. This feature distinguishes the premises of the Austrian School from the Chicago approach to competition. Aside from historical differences, related to the fact that the Chicago School has been considered as a mainstream antitrust theory, while the Austrian approach is seen mostly as a heterodox vision, leaving it more room for the elaboration of non-empirical normative claims without direct application in the economic life, the main methodological difference between Austrians and Chicagoans is that the latter rely exclusively on economic analysis, referring to the empirical fact that the principles

156 Nils Goldschmidt \& Hermann Rauchenschwandtner, The Philosophy of Social Market Economy: Michel Foucault's Analysis of Ordoliberalism, Freiburg Discussion Papers on Constitutional Economics, 07/04, 2007, 2: '[T]he idea of competition as 'eidos' (instead of a natural given) is central to ordoliberalism'.

157 Rudolph J. Peritz, supra n. 2, 264: 'What do we want to free competition from? Do we want to free it from governmental power? Or from market power?’

158 Roger Zäch, Economic Theory and Competition Law 122-123 (Josef Drexl, Laurence Idot \& Joël Monéger eds., Edward Elgar 2009) : 'The underlying rationale is that freedom to compete leads to competition and competition leads to economic and social welfare.'

159 Wolfgang Kerber, The Elgar Companion to Austrian Economics 501 (Peter J. Boettke ed., Edward Elgar 1994): 'It has always been as essential characteristic of German [as well as Austrian] market process theory that competition was understood as producing economic and technical progress'.

160 Viktor J.Vanberg, supra n. 114, 2.

161 Norman P. Barry, The New Liberalism, 13 British J. Pol. Sci. 93 (1983): 'Broadly speaking, libertarians may be divided into two groups; 'consequentialists' and 'rights' theorists. [...]The consequentialist libertarians $[\ldots]$ maintain that $[\ldots]$ benefits to society at large come spontaneously from the pursuit of individual satisfactions.' 
of competition work best, while the former merely supplement their political theory by reference to this empirical fact. ${ }^{162}$ The positivist approach, which Barry attributes to the Chicago School, is typical of the economic reasoning in general. It should not be either criticized or eliminated, since its normative simplicity "what is good must be right' eliminates many misunderstandings, making the method of economics work. However, workability is not the sole feature of societal systems, and those theories which apart from a sound economic analysis develop a normative theoretical support can address the same set of problems both in consequentialist as well as in deontological terms. ${ }^{163}$ Both approaches did not ignore social needs, but considered that these issues should be resolved via taxation rather than antitrust. ${ }^{164}$ The Chicago School, however, limited competition analysis to its welfare-effects, while Austrians emphasized the importance of the competitive process, which goes beyond neoclassical calculus.

\section{CONCLUSIONS}

The deontological ethos is important for both Ordoliberalism and Austrianism. A deontological perception of competition means that the competitive process should not be measured nor legitimized by its eventual positive impact on the economy. ${ }^{165}$ According to Hayek, 'a highly developed commercial spirit is itself as much the product as the condition of effective competition [... W] know of no other method of producing it that to throw competition open to all who want to take advantage of the opportunities it offers'. ${ }^{166}$ The reduction of competition to its positive, welfare-enhancing elements removes the peculiar features of the competitive process like 'chance, uncertainty, and unpredictability in human life', ${ }^{167}$ which were most clearly advocated by the Austrian School. Kerber puts the issue of uncertainty into a broader theoretical perspective, describing different

162 Norman P. Barry, supra n. 160, 95-96: 'The Chicago School of Economics is systematically positivist. [...]Its followers not only accept the distinction between fact and value but also implicitly accept the highly dubious metaphysical proposition that, apart from the tautologies of mathematics and formal logic, the only meaningful statements are observational statements (even if the purported observations are theoretical rather than practicable). [...] Any theoretical proposition not derived from experience must be purely tautologous and therefore incapable of conveying empirical knowledge'.

163 Norman P. Barry, supra n. 160, 121.

164 Herbert J. Hovenkamp, supra n. 110, 245: 'If efficiency goals and distributive goals can really be separated, then it would appear that the duty of the Chicago School antitrust policymaker is to look only at the efficiency effects of a policy and ignore any distributional effects. Unpopular distributional effects can be corrected later by a different policy.'

165 Jonathan Wolff, Libertarianism, Utility and Economic Competition, 92 Va L. Rev. 1606-1607 (2006) : ' $[\mathrm{T}]$ hose that reject consequentialist reasoning, such as deontological libertarians, are not entitled to avail themselves of [... utilitarian] solutions.'

166 Friedrich A. von Hayek, The Political Order of a Free People, vol. 3, 73 (Routledge \& Kegan Paul, 1976).

167 Paul A. Cantor \& Stephen Cox, Literature and the Economics of Liberty: Spontaneous Order in Culture xi (Paul A. Cantor \& Stephen Cox eds., Ludwig von Mises Institute 2009). 
advantages of diversity as explored in different disciplines. ${ }^{168}$ The inevitability of uncertainty and the possibility of its fruitful internalization into the philosophy of science has been emphasized by Polanyi. ${ }^{169}$ Ordoliberal thinkers as Hoppmann also emphasized the importance of the freedom to compete, perceiving it as part of the essence of the economic constitution, ${ }^{170}$ and a goal in itself. ${ }^{171}$ For Hoppmann the outcomes of the competitive process 'are inherently unpredictable [... and ] market outcomes can rarely be unambiguously attributed to individual acts', ${ }^{172}$ as freedom and predictability seldom coincide.

By constitutionalization of the competitive process, it has been argued that both welfare and competition are important public goods. ${ }^{173}$ This approach brings together economic and political freedoms. ${ }^{174}$

The criticism which such a perception of competition can generate is manifold, though it can be reduced to two major aspects: (i) empirical and (ii) normative:

(i) On the empirical side, the dis-equilibration of competition raises concerns about its proper definition, measurement and evaluation. As Hughes argues, the alternative to the mainstream antitrust analysis should not be limited to its criticism and promotion of empty slogans, suggesting that ' $\mathrm{t}]$ he Chicago School approach is successful in large part because it is based on economic principles that are simple enough to be manageable'. ${ }^{175}$ Indeed, by abandoning the methodological framework of perfect competition, the competitive process abandons also the potential for being defined in economically verifiable terms. This problem has two connected solutions, an apologetic and an apagogical one. The former reveals that it was the intention of the founders of the concept of competition as a discovery process of 'challenge and response', ${ }^{176}$ to eliminate the predictability of competition. Hayek emphasizes that it is exactly the essence of competition, which requires it to remain unpredictable and immeasurable, thus

Wolfgang Kerber, supra n. 89, 177-179.

Michael Polanyi, The Value of the Inexact, 3 Phil. Sci. 233 (1936).

Wolfgang Kerber \& Ulrich Schwalbe, supra n. 43, 229-230: 'On the basis of [... the] Ordoliberal ideas [Erich] Hoppmann developed his concept of freedom of competition in the late 1960s and the 1970s. [...] On the normative level, he criticized vehemently the view that competition is primarily an instrument to achieve economic aims. Instead he considered individual freedom as the most important aim. [...] Freedom of competition means, on the other hand, the (entrepreneurial) freedom of firms $[\ldots]$ and, on the other hand, the freedom of buyers and sellers.'

171 Erich Hoppmann, Wettbewerb als Norm der Wettbewerbspolitik, 18 Ordo - Jahrbuch für die Ordnung von Wirtschaft und Gesellschaft 79 (1967), translated and quoted in Viktor J.Vanberg, supra n. 12, 9.

172 Heike Schweitzer, supra n. 125, 522.

173 Viktor J.Vanberg, supra n. 114, 15.

174 Patricia Owens, The Ethic of Reality in Hannah Arendt 151 (Oxford University Press 2008): 'Politics and freedom, public freedom, are fundamentally ends in themselves.'

175 Edwin J. Hughes, supra n. 59, 287.

176 Donald Dewey, The Economic Theory of Antitrust: Science or Religion?, 50 Va. L. Rev. 421 (1964). 
abandoning scientism. ${ }^{177}$ Competition thereby abandons to a large extent the realm of science, not being subject to verifiability requirements, and shifts to the realm of ideological choices in society, something, which can be justified intuitively, as a matter of societal culture, but not defined in the pragmatic language of economic analysis. The apagogical explanation operationalizes an a contrario argument, according to which the predictions and measurements of such important economic values, by which competition is often measured, as consumer or total welfare, industrial growth, innovation and market integration similarly fail to meet the unanimous standard of evaluation. The evolution of competition law shows that each of these concepts holds significant elements of ambiguity, inductive context-dependency and multiple meanings. ${ }^{178}$

(ii) The normative argument supports the empirical one, and mitigates the difficulties related to the dis-equilibration of the competitive process. Acknowledgment of the constitutional importance of competitive process and its perception as a paramount value of liberal democracy does not prioritize competition or immunize it against regulatory limitations. Pluralistic democracies constantly face the necessity to make choices between equally important societal values. These values therefore compete with each other for being prioritized by the decision-makers. ${ }^{179}$ By disentangling competition from utilitarian values, the regulator will be able to decide which of the values is more important in each particular case. While measurable values would argue their case by applying the economic rationale of equilibrium-based reasoning, more deontological values would participate in this competition using their own specific deontological instruments. This approach would benefit from the elements of competing interdisciplinary methods, which as Kerber argues are necessary for defining and regulating the normative foundations of competition law, ${ }^{180}$ and undermine the influential holistic view that 'only efficiency and consumer welfare are appropriate normative goals of competition law'. ${ }^{181}$

The methodological similarities of these deontological schools should not be oversimplified. This synthetic unification is made for epistemological purposes only, in order to articulate the dynamic aspects of the market process, which both schools support. They are taken jointly therefore only to illustrate their deontological approaches to competition, which differ to a large extent, but often complement each other, if taken from the dialectical stand. This artificial epistemic

\footnotetext{
177 Friedrich A. von Hayek, supra n. 77, 10 (emphasis in the original): '[T] he validity of the theory of competition can never be empirically verified for those cases in which it is of interest.'

178 Heike Schweitzer, supra n. 125, 513: 'Various conceptions of a "more economic approach" compete with each other'.

179 Maher M. Dabbah, supra n. 32, 54-55.

180 Wolfgang Kerber, supra n. 17, 18.

181 Roger J.Van den Bergh \& Peter D. Camesasca, supra n. 62, 18.
} 
model helps to address the essence of competition as a phenomenon, without focusing on ideological issues, which constantly arise in such a paradoxical area of law as antitrust. ${ }^{182}$ The two deontological doctrines significantly differ in respect to their broader views on the role of public instruments in the regulation of economic affairs and therefore are seldom considered as theoretical allies. The hypothesis of this research is that, despite substantial ideological discrepancies, the deontological antitrust schools hold the same methodological views concerning the conceptual independency of the competitive process; adhering to its separation from the outcomes, which it can deliver for society. Regardless of their ideological differences (and in some dialectical sense 'due to' these differences) the two deontological approaches reinforce each other. It is important therefore to articulate the methodological similarities of the deontological antitrust schools. As Heinemann argues, ${ }^{183}$ the emphasis on the discovering nature of the competitive process is an ideologically neutral concept, which can be in conformity with interventionist policy as well as with a libertarian one. The synthesis of Ordoliberalism and Austrianism provides a theoretical paradigm where the liberal constitutionalism of the former supplements and invigorates the constitutional liberalism of the latter, ${ }^{184}$ without solving the dilemmatic relations between the two, but placing them into a dialectical interplay of strong government, protecting multiple goals, among which the freedom to compete holds an important position.

\footnotetext{
182 Yane Svetiev, Antitrust Governance: The New Wave of Antitrust, 38 Loy. U. Chi. L.J. 597 (2007): 'The paradox of this field of law is evident - antitrust tries to save the market mechanism from itself which means that it has no strong friends either among free-marketers or interventionists.'

183 Andreas Heinemann, Competition Policy and the Economic Approach: Foundations and Limitations 210-211 (Josef Drexl, Wolfgang Kerber \& Rupprecht Podszun eds., Edward Elgar 2011).

184 Viktor J. Vanberg, Liberal Constitutionalism, Constitutional Liberalism and Democracy, Freiburg Discussion Papers on Constitutional Economics, 09/04, 2009, 9.
} 